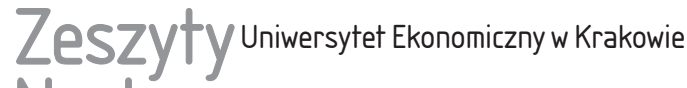 Naukowe
}

\section{Koncepcja informatycznego systemu rezerwacji zasobów w sądach powszechnych*}

\section{Streszczenie}

W artykule przedstawiono koncepcję dobrej praktyki informatycznej w zakresie zarządzania zasobami rzeczowymi organizacji, która powstała podczas wdrożenia pilotażu dobrego zarządzania jednostkami wymiaru sprawiedliwości w ramach projektu „PWP Edukacja w dziedzinie zarządzania czasem i kosztami postępowań sądowych - case management” programu operacyjnego „Kapitał ludzki”. Opisano także cele dobrej praktyki, jej części składowe oraz efekty, jakie przyniosło jej wdrożenie.

Słowa kluczowe: ITSM, dobra praktyka, sądownictwo, technologia informacyjna. Klasyfikacja JEL: M15, K00.

\section{Wprowadzenie}

W artykule przedstawiono koncepcję dobrej praktyki poświęconej informatycznemu systemowi rezerwacji zasobów powstałej podczas realizacji projektu „PWP Edukacja w dziedzinie zarządzania czasem i kosztami postępowań sądowych - case management” programu operacyjnego „Kapitał ludzki”. Opracowanie

Mariusz Grabowski, Uniwersytet Ekonomiczny w Krakowie, Wydział Zarządzania, Katedra Systemów Obliczeniowych, ul. Rakowicka 27, 31-510 Kraków, e-mail: grabowsm@uek.krakow.pl, ORCID: https://orcid.org/0000-0002-7434-9964.

* Artykuł powstał w wyniku prac nad projektem pt. „PWP Edukacja w dziedzinie zarządzania czasem i kosztami postępowań sądowych - case management”, nr projektu POKL.05.03.00-00-012/11. 
i wdrożenie wielu dobrych praktyk przeprowadzono w latach 2013-2014, zaś po roku od zakończenia wdrożenia zostały opublikowane raporty podsumowujące oraz badania ewaluacyjne. Koncepcje dobrych praktyk informatycznych zostały zaoferowane do implementacji w 60 sądach różnych szczebli na terenie Polski. Otoczenie i fazy projektu szerzej przedstawiono w artykule (Grabowski, Madej i Trąbka 2018).

Celem niniejszego artykułu jest przedstawienie zaproponowanej w ramach wspomnianego projektu koncepcji informatycznego systemu rezerwacji zasobów. Zarządzanie zasobami należy do głównych działań wpływających na efektywność funkcjonowania organizacji, dlatego zagadnienie to jest przedmiotem zainteresowań zarówno w teorii, jak i w praktyce. Sąd nie jest organizacją rynkową, jednak z doświadczeń podmiotów biznesowych wynika, że podstawowym elementem skutecznego i efektywnego zarządzania zasobami jest ich optymalizacja i koordynacja wykorzystania do osiągania celów organizacyjnych (Wade i Hulland 2004). Projektując omawiane rozwiązanie, wzorowano się na koncepcji scentralizowanego systemu rezerwacji zasobów, który jako pierwszy został skutecznie i efektywnie zaimplementowany w branży lotniczej w postaci systemu rezerwacji miejsc lotniczych central reservation systems - CRS (Copeland i McKenney 1988, Duliba, Kauffman i Lucas Jr. 2001). Następnie rozwiązanie to zostało zaadaptowane w branży hotelarskiej (Lin i Lee 2010) oraz zaczęło być powszechnie stosowane w internetowych systemach rezerwacji lotów, hoteli i samochodów zwanych general distribution systems - GDS (Chircu, Kauffman i Keskey 2001), stanowiąc integralny i strategiczny składnik technologiczny w tych branżach.

Istotna jest odpowiedź na pytanie, na ile rozwiązania z obszaru biznesu mogą znaleźć zastosowanie na gruncie instytucji sądowniczych, dlatego należało skupić się na uwarunkowaniach i specyfice sądów. Na podstawie przeprowadzonej analizy bibliograficznej można stwierdzić, że istnieje niewielka liczba artykułów naukowych dotyczących wdrożeń z dziedziny IT w obszarze sądów. Istnieją nieliczne artykuły zagraniczne omawiające wybrane rozwiązania mające na celu dostosowanie do specyfiki prawodawstwa danego kraju (np. Bueno i in. 2003, Luzuriaga i Cechich 2011, Gorham 2012).

Zrozumienie otoczenia projektowego, przedstawionego szerzej w artykule wprowadzającym (Grabowski, Madej i Trąbka 2018), miało istotne znaczenie w procesie wyboru metodyki badawczej oraz w konsekwencji wpłynęło na kształt opracowanych praktyk. Wybrano podejście action research (AR, badania w działaniu) jako główną metodykę w realizacji opisywanego projektu (Baskerville i Wood-Harper 1996, Baskerville 1999, Davison, Martinsons i Kock 2004, Cole i Avison 2007). Zaproponowane koncepcje dobrych praktyk z wykorzystaniem podejścia AR zostały sformułowane w wyniku współpracy z pracownikami sądu, 
obserwacji rozwiązań stosowanych w sądach i wynikających z potrzeb zgłaszanych przez ich pracowników. W niektórych przypadkach zaproponowane praktyki nie były nowością w sądach, jednakże różny był ich stopień wykorzystania lub też różne były potrzeby pracowników. Dlatego wyróżniono kilka poziomów wdrażania dobrych praktyk zgodnie z koncepcją poziomów dojrzałości (Paulk i in. 1993, COBIT 4.1... 2010).

Powstała koncepcja dobrej praktyki, która jest efektem procesu badawczego z wykorzystaniem AR. Kompozycja artykułu odpowiada poszczególnym etapom realizacji projektu. W pierwszej kolejności omówiony został proces opracowania listy dobrych praktyk, które zostały później przedstawione do akceptacji przedstawicielom sądów. Informacja o tym, które z praktyk i w jakich sądach zostaną skierowane do implementacji, stanowi rezultat procesu badawczego.

\section{Obowiązujące regulacje i normy}

Przedmiotem omawianej w artykule dobrej praktyki jest wdrożenie w sądach biorących udział w pilotażu dobrej praktyki informatycznego systemu rezerwacji zasobów. Wdrażając opisane poniżej rozwiązanie, należy uwzględnić zapisy Rozporządzenia Rady Ministrów z dnia 12 kwietnia 2012 r. w sprawie Krajowych Ram Interoperacyjności, minimalnych wymagań dla rejestrów publicznych i wymiany informacji w postaci elektronicznej oraz minimalnych wymagań dla systemów teleinformatycznych (Dz.U. 2012, nr 0, poz. 526). Ponadto należy uwzględnić obowiązujące regulacje prawne zawarte w: Ustawie z dnia 27 lipca 2001 r. - Prawo o ustroju sądów powszechnych (Dz.U. nr 98, poz. 1070 ze zm.), Ustawie z dnia 18 grudnia 1998 r., o pracownikach sądów i prokuratury (Dz.U. z 2011, nr 109, poz. 639 ze zm.) oraz Zarządzeniu Ministra Sprawiedliwości z dnia 27 czerwca 2012 r. w sprawie wprowadzenia Polityki Bezpieczeństwa Informacji Ministerstwa Sprawiedliwości i sądów powszechnych (Dz.Urz. Ministerstwa Sprawiedliwości, poz. 93). Należy uwzględnić także niektóre zasady zawarte w standardzie COBIT - Control Objectives for Information and related Technology.

Rozwiązania opisane w niniejszej praktyce oparto się na doświadczeniach wynikających z wdrożeń przeprowadzonych w organizacjach gospodarczych. Skuteczne i efektywne zarządzanie zasobami może się przełożyć na poprawę efektywności postępowań sądowych zarówno w wymiarze czasowym, jak i finansowym. Praktyka dotyczy wszystkich pracowników sądu, w szczególności zaś pracowników oddziału informatycznego. 


\section{Korzyści wynikające $z$ wdrożenia dobrej praktyki informatycznego systemu rezerwacji zasobów}

Celem dobrej praktyki jest wdrożenie wspomaganych informatycznie narzędzi organizacyjnych w obszarze zarządzania zasobami niezbędnymi do realizacji działalności orzeczniczej i administracyjnej sądu. Zarządzanie zasobami w aspekcie całego sądu to badanie dostępności i obciążenia poszczególnych zasobów oraz ich grup, tak by było możliwe optymalne nimi gospodarowanie.

W bieżącej działalności sąd wykorzystuje rozmaite zasoby. Można je podzielić na trzy kategorie: lokalowe, rzeczowe oraz osobowe. Do zasobów lokalowych zalicza się sale rozpraw, sale konferencyjne, sale o charakterze specjalnym, np. „błękitny pokój” czy sala rozpraw z możliwością prowadzenia telekonferencji. Zasoby rzeczowe obejmują najczęściej sprzęt specjalistyczny, np. zestaw multimedialny do prezentacji materiału dowodowego. Zasoby osobowe stanowią pracownicy organizacji. W praktyce mogą wystąpić trudności w określeniu dostępności zasobu we wszystkich wskazanych wyżej kategoriach. Sytuację komplikuje dodatkowo fakt, że część zasobów pozostaje w dyspozycji poszczególnych wydziałów sądu, a część ma charakter centralny. W przypadku zasobów przypisanych do poszczególnych wydziałów niektóre z zasobów mogą mieć charakter nadmiarowy (ten sam rodzaj zasobu istniejący jednocześnie na kilku wydziałach przy jego niepełnym wykorzystaniu), natomiast w przypadku zasobów centralnych określone zasoby mogą być wykorzystywane w sposób nieoptymalny.

Poprawy efektywności zarządzania zasobami w skali całego sądu można dokonać poprzez wprowadzenie wspomagania informatycznego mającego na celu:

- udostępnienie informacji o zasobie obejmującej wybór samego zasobu (lub grupy zasobów) oraz sprawdzenie stanu opisujących go parametrów,

- zapewnienie możliwości rezerwacji zasobu w określonym terminie, z możliwością ewentualnej późniejszej zmiany terminów rezerwacji,

- uzyskanie informacji dotyczącej stopnia wykorzystania poszczególnych zasobów oraz grup zasobów w określonym przedziale czasu.

Spełnienie powyższych postulatów pozwoli nie tylko na skrócenie procesu rezerwacji zasobów i zapewnienie lepszej kontroli nad wykorzystaniem zasobów, ale pozwoli również na optymalizację struktury posiadanych zasobów oraz wpłynie na poprawę efektywności przyszłych zakupów.

Podstawowym mechanizmem umożliwiającym implementację praktyki jest udostępnienie kalendarzy dla poszczególnych zasobów. W tym przypadku pracownik jest szczególnego rodzaju zasobem, a przedmiotem rezerwacji jest jego czas. Funkcjonalność ta nabiera istotnego znaczenia w przypadku konieczności informowania i koordynowania działań pracowników, których praca nie jest rutynowa (np. prezes 
sądu), zorganizowania zebrania dla grupy pracowników lub koordynacji działań w trakcie sezonu urlopowego.

Korzyści z wdrożenia dobrej praktyki mogą być rozpatrywane w trzech aspektach:

1) organizacji pracy:

- zwiększenie dostępności zasobów przy ich ograniczonej ilości,

- identyfikacja i eliminacja zasobów zdublowanych,

- identyfikacja zasobów niedoszacowanych,

- identyfikacja sezonowości w wykorzystaniu zasobów,

- koordynacja działań wybranych pracowników i grup pracowników,

- poprawa efektywności procesu rezerwacji zasobów,

- poprawa celowości planowania zakupu nowych zasobów;

2) pracownika:

- ułatwienie dostępu do informacji o dostępności i parametrach zasobów,

- skrócenie czasu rezerwacji zasobu, zmiany terminów oraz ewentualnego anulowania rezerwacji,

- poprawa ergonomii procedury rezerwacji zasobów,

- możliwość koordynowania działań z innymi pracownikami;

3) finansowym:

- zmniejszenie kosztów procesu rezerwacji zasobów,

- zmniejszenie kosztów pozyskania i utrzymania zasobów.

\section{Opis procesu opracowania dobrej praktyki informatycznego systemu rezerwacji zasobów}

\subsection{Określenie założeń, zakresu i funkcji dobrej praktyki}

Wdrożenie informatycznego systemu rezerwacji zasobów na ogół nie jest złożonym przedsięwzięciem wymagającym długookresowych działań oraz środków finansowych. Jego zakres zależy od zaawansowania istniejącej infrastruktury informatycznej. W przypadku gdy sąd stosuje zaawansowane narzędzia komunikacji wewnętrznej, takie jak MS Exchange lub Zimbra, bądź używa serwisu intranetowego opartego na systemie zarządzania treścią (np. Joomla!), wdrożenie praktyki może zostać ograniczone do poszerzenia funkcjonalności istniejącego oprogramowania i będzie mieć charakter organizatorsko-administracyjny. W przypadku braku istnienia takich rozwiązań wdrożenie może mieć bardziej złożony charakter.

Koszty wdrożenia praktyki obejmują koszty zakupu sprzętu i oprogramowania i przeszkolenia administratora systemu oraz użytkowników systemu. Dobra praktyka zakłada wykorzystanie istniejącego sprzętu oraz oprogramowania open 
source (lub innego darmowego czy też wcześniej zakupionego oprogramowania komercyjnego), co w praktyce może oznaczać ograniczenie wydatków do kosztów szkolenia.

\subsection{Faza przygotowawcza}

Faza przygotowawcza ma na celu określenie zakresu wdrożenia i jest procesem składającym się z czterech etapów: wstępnej oceny poziomu dojrzałości, weryfikacji poziomu dojrzałości, określenia docelowego poziomu dojrzałości oraz wyboru metod i narzędzi koniecznych do osiągnięcia poziomu docelowego. Proces definiowania zakresu wdrożenia zaprezentowano na rys. 1.

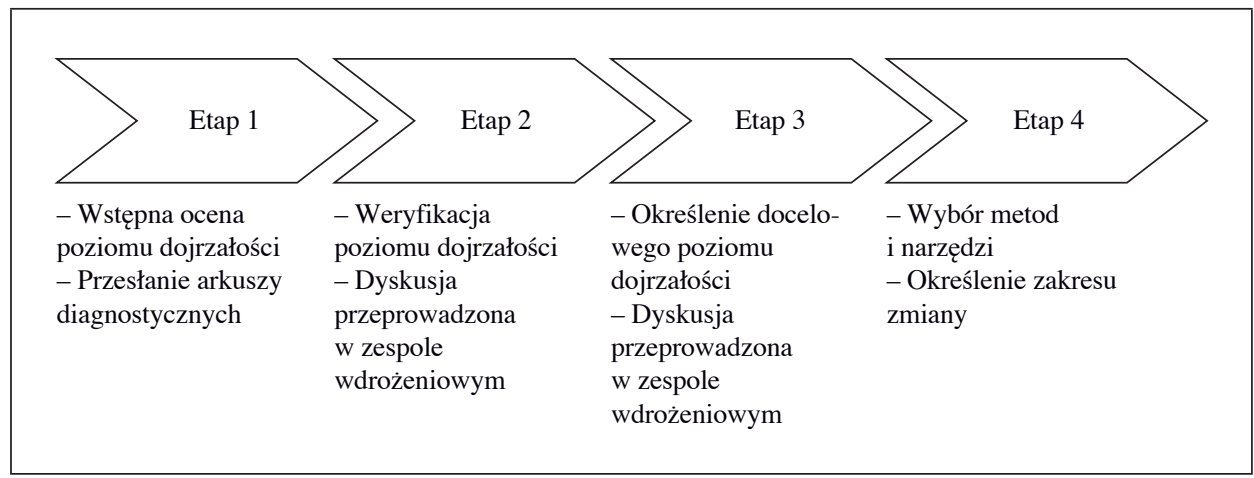

Rys. 1. Proces definiowania zakresu wdrożenia Źródło: (Grabowski 2018, s. 195).

Etap pilotażowy obejmował badanie ankietowe wybranych sądów, w celu określenia poziomu dojrzałości organizacji w stosowaniu omawianej dobrej praktyki (zgodnie z tabelą 1). Etap 1 fazy przygotowawczej został ukończony. Zebrane odpowiedzi traktowane są jako ocena wstępna. Kolejnym etapem jest wdrożenie, podczas którego należy dokonać weryfikacji oceny poziomu dojrzałości, a następnie określić poziom docelowy. Weryfikacja poziomu dojrzałości może wykazać, że pomimo spełnienia wymagań poziomu wyższego, istnieją braki dotyczące spełnienia wymogów poziomu niższego. W następnym etapie istotne jest określenie poziomu docelowego, co z kolei determinuje wybór odpowiedniego zestawu narzędzi, który ma na celu dopasowanie praktyki do specyfiki sądu. Proces dopasowania wdrażanej praktyki powinien mieć formę dyskusji przeprowadzonej w zespole wdrożeniowym (w skład którego, oprócz przedstawicieli 
firmy wdrożeniowej, wchodzą również pracownicy sądu) oraz zostać zakończony konsensusem odnośnie do zakresu dokonywanych zmian.

Przy określaniu zakresu zmian należy kierować się zdrowym rozsądkiem, tzn. preferować zmiany małe $\mathrm{z}$ ich ewentualnym późniejszym rozszerzeniem.

Tabela 1. Poziomy dojrzałości dobrej praktyki „Informatyczny system rezerwacji zasobów”

\begin{tabular}{|c|l|l|}
\hline Poziom & Nazwa poziomu & \multicolumn{1}{|c|}{ Wymagania } \\
\hline I & Początkowy & $\begin{array}{l}\text { Lokalne aplikacje (np. opracowane arkusze kalkulacyjne) } \\
\text { wykorzystywane przez poszczególne jednostki sądu }\end{array}$ \\
\hline II & $\begin{array}{l}\text { Powtarzalny, } \\
\text { lecz intuicyjny }\end{array}$ & Sieciowa (serwerowa) scentralizowana aplikacja \\
\hline III & Zdefiniowany & $\begin{array}{l}\text { Kalendarz prezesa sądu, dyrektora i innych osób na kierow- } \\
\text { niczych stanowiskach }\end{array}$ \\
\hline IV & $\begin{array}{l}\text { Kontrolowany } \\
\text { i mierzalny }\end{array}$ & $\begin{array}{l}\text { Sformalizowana metoda rezerwacji oraz mierniki wykorzy- } \\
\text { stania zasobów }\end{array}$ \\
\hline V & Zoptymalizowany & $\begin{array}{l}\text { Analiza trendów (obciążenia wykorzystywania zasobów), } \\
\text { analiza potrzeb użytkowników i modyfikacja modelu rezer- } \\
\text { wacji zasobów }\end{array}$ \\
\hline
\end{tabular}

Źródło: opracowanie własne.

Tabela 2. Spis nieodpłatnego oprogramowania do rezerwacji zasobów

\begin{tabular}{|c|c|c|}
\hline Wyszczególnienie & Typ systemu & Opis \\
\hline $\begin{array}{l}\text { 1.Zimbra (http:// } \\
\text { www.zimbra.com/) }\end{array}$ & $\begin{array}{l}\text { System rezerwacji } \\
\text { zasobów zinte- } \\
\text { growany z pocztą } \\
\text { elektroniczną } \\
\text { i systemem pracy } \\
\text { zespołowej }\end{array}$ & $\begin{array}{l}\text { Zimbra Collaboration Suite (ZCS) jest systemem klasy } \\
\text { enterprise integrującym zaawansowane rozwiązania } \\
\text { poczty elektronicznej, kalendarza oraz rozwiązań } \\
\text { pracy zespołowej uruchamianych z poziomu serwera. } \\
\text { ZCS Open Source Edition jest udostępniane na pod- } \\
\text { stawie EULA (pliki binarne) oraz ZPL (kod źródłowy) } \\
\text { i może być nieodpłatnie wykorzystywane w dowolnych } \\
\text { zastosowaniach }\end{array}$ \\
\hline $\begin{array}{l}\text { 2. Joomla!/JEvents } \\
\text { (http://www. } \\
\text { jevents.net) }\end{array}$ & $\begin{array}{l}\text { Kalendarz jako } \\
\text { moduł systemu } \\
\text { CMS }\end{array}$ & $\begin{array}{l}\text { JEvents jest modułem systemu zarządzania treścią } \\
\text { Joomla! Zawiera rozbudowany system kalendarzowy } \\
\text { pozwalający na zarządzanie uprawnieniami poszcze- } \\
\text { gólnych użytkowników systemu Joomla! } \\
\text { Podstawowa wersja systemu udostępniona jest na } \\
\text { zasadach licencji GNU GPLv2, można ją więc nie- } \\
\text { odpłatnie używać we wszelkiego rodzaju zastosowa- } \\
\text { niach. Dodatkowe funkcjonalności można uzyskać na } \\
\text { zasadzie płatnej subskrypcji }\end{array}$ \\
\hline
\end{tabular}


cd. tabeli 2

\begin{tabular}{|l|l|l|}
\hline Wyszczególnienie & \multicolumn{1}{|c|}{ Typ systemu } & \multicolumn{1}{c|}{ Opis } \\
\hline $\begin{array}{l}\text { 3. phpSheduleIt } \\
\text { (http://twinkleto- } \\
\text { essoftware.com/ } \\
\text { products) }\end{array}$ & $\begin{array}{l}\text { Niezależny system } \\
\text { do rezerwacji } \\
\text { zasobów }\end{array}$ & $\begin{array}{l}\text { phpScheduleIt jest systemem działającym na serwerze } \\
\text { WWW pozwalającym na rezerwację zasobów oraz } \\
\text { zarządzanie ich wykorzystaniem. Posiada on rozbudo- } \\
\text { wany system raportowania. Do instalacji oprogramo- } \\
\text { wania wymagane są: serwer www zawierający moduł } \\
\text { PHP oraz baza mySQL. } \\
\text { Oprogramowanie jest udostępniane na podstawie } \\
\text { licencji GNU GPLv3, można je więc nieodpłatnie } \\
\text { używać we wszelkiego rodzaju zastosowaniach }\end{array}$ \\
\hline $\begin{array}{l}\text { 4. WebCalendar } \\
\text { (http://www.k5n. } \\
\text { us/webcalendar. } \\
\text { php) }\end{array}$ & $\begin{array}{l}\text { Niezależny system } \\
\text { do zarządzania } \\
\text { kalendarzami } \\
\text { i wydarzeniami }\end{array}$ & $\begin{array}{l}\text { WebCalendar jest narzędziem o podobnej funkcjonal- } \\
\text { ności do phpScheduleIt, jednak w większym stopniu } \\
\text { uwzględnia zarządzanie kalendarzami osób. Oprogra- } \\
\text { mowanie jest udostępniane na podstawie licencji GNU } \\
\text { GPLv2, można je więc nieodpłatnie używać we wszel- } \\
\text { kiego rodzaju zastosowaniach }\end{array}$ \\
\hline
\end{tabular}

Źródło: opracowanie własne.

W tabeli 1 zaprezentowano poziomy dojrzałości dobrej praktyki mającej na celu implementację informatycznego systemu rezerwacji zasobów. Następnie opisano metody i narzędzia informatyczne wykorzystywane na jej poszczególnych poziomach. Narzędzia informatyczne zestawiono w tabeli 2 oraz opisano w pkt 4.4.

\subsection{Proces dopasowywania praktyki do potrzeb sądu}

Bez względu na wybrany poziom dojrzałości proces dopasowania praktyki do potrzeb sądu jest realizowany w następujących etapach:

1) inwentaryzacja zasobów lokalnych i centralnych, czyli identyfikacja wszystkich zasobów lokalowych, rzeczowych i osobowych będących w dyspozycji sądu istotnych ze względu na optymalizację ich użycia. Mogą do nich należeć: sale rozpraw, sale konferencyjne, „błękitny pokój”, projektory, notebooki, nagrywarki, zestawy multimedialne. Na szczególną uwagę zasługują zasoby osobowe, które w istocie nie będą rezerwowane, ale informacja o ich dostępności będzie przydatna do koordynacji działań, w tym kalendarze prezesa sądu, wiceprezesów, dyrektora sądu, przewodniczących wydziałów, kierowników oddziałów i innych pracowników. Warto również określić zasoby szczególnie krytyczne dla funkcjonowania sądu, tzn. takie, które są rzadkie w swej naturze i wymagają dodatkowej akceptacji kierownika jednostki (np. samochód służbowy). W tym punkcie wymieniono jedynie przykłady zasobów. Określony zestaw zasobów będzie uzależniony od decyzji danej jednostki. Zakres ten może również być rozszerzany stopniowo, podczas wdrażania dobrej praktyki; 
2) określenie zasobów przeznaczonych do informatyzacji procedury zarządzania, którego celem jest identyfikacja jedynie tych zasobów, które wejdą w zakres funkcjonowania praktyki. Przykładowo sądy, w których funkcjonuje system SWOR (system wspomagania organizacji rozpraw), mogą nie być zainteresowane zarządzaniem salami rozpraw. Może również okazać się, że jedyną pożądaną funkcjonalnością będzie koordynowanie pracy osób zajmujących kierownicze stanowiska. Część zasobów, szczególnie te, które są wykorzystywane rzadko, może zostać celowo przeznaczona jedynie do zarządzania metodą tradycyjną, która nie korzysta ze wsparcia informatycznego;

3) instalacja i konfiguracja oprogramowania, która jest zależna od docelowego modelu praktyki oraz od posiadanej obecnie infrastruktury informatycznej. Szczegółowe informacje dotyczące potencjalnego zakresu prac instalacyjno-wdrożeniowych zawarto w pkt 4.4;

4) przypisanie kalendarzy do poszczególnych zasobów, polegające na połączeniu zasobów z określonymi kalendarzami, użytkownikami oraz grupami użytkowników. Zarządzanie powiązaniami pomiędzy zasobami, kalendarzami i użytkownikami jest procesem złożonym, ponieważ powinno ono uwzględniać wymagania polityki bezpieczeństwa, tzn. przypisanie takich uprawnień użytkownikom, które pozwolą na skuteczne i efektywne funkcjonowanie praktyki. Oznacza to, że system ten powinien przyznawać uprawnienia jedynie na poziomie minimalnym. W praktyce oznacza to, że do niektórych zasobów dostęp będą mieć tylko wybrani użytkownicy, a niektóre będą powszechnie dostępne, przy czym dostęp do zasobu może mieć charakter jedynie jego przeglądania lub rozszerzać tę funkcjonalność na możliwość tworzenia, edycji i kasowania. Proces ten w szczególności powinien uwzględniać:

- przypisanie opiekunów do poszczególnych zasobów, tzn. osób odpowiedzialnych za zarządzanie zasobem,

- przypisanie dodatkowych atrybutów zasobów poszerzających informację go opisującą, jeśli zajdzie taka konieczność,

- autoryzacja w procesie rezerwacji zasobu, czyli określenie procedury zatwierdzającej rezerwację lub jej zmianę - za proces rezerwacji zasobu odpowiedzialni są właściciele zasobu, ale w niektórych przypadkach (np. w przypadku zasobów krytycznych) potrzebna może okazać się dodatkowa autoryzacja kierownika jednostki;

5) definiowanie raportów obciążenia zasobów polegające na analizie stopnia i cykliczności ich wykorzystania. Raporty te mogą stanowić podstawę do zmian w strukturze posiadanych zasobów poprzez ewentualne ich przesunięcia pomiędzy jednostkami organizacyjnymi lub planowanie przyszłych zakupów i zmiany w zatrudnieniu. 
Niektóre z wyżej wymienionych etapów będą mieć charakter cykliczny. W szczególności dotyczy to kroków 2, 4 i 5.

\subsection{Opis poziomów dojrzałości}

Poziom I - poczq̨tkowy. Podstawowym elementem budowy systemu rezerwacji zasobów jest dokumentowanie czasu rezerwacji poszczególnych zasobów. W tym celu można wykorzystać np. arkusz kalkulacyjny MS Excel, który pozwala na użycie wzorców dokumentów w postaci kalendarza. W takim przypadku system ogranicza się do zbioru plików w formacie arkusza kalkulacyjnego przechowywanych w folderach, do których dostęp mają opiekunowie poszczególnych zasobów. Wersja bardziej rozbudowana funkcjonalnie może pozwalać na umieszczenie tych plików w sieciowych folderach współdzielonych, przy czym ważnym jej elementem jest właściwe określenie konwencji nazewnictwa plików oraz atrybutów plików i uprawnień dla poszczególnych użytkowników na poziomie systemu operacyjnego.

Dzięki zastosowaniu tych mechanizmów możliwy będzie dostęp do plików opisujących zarezerwowane zasoby na poziomie ograniczonym jedynie do odczytu dla szerszych grup użytkowników, a możliwości zmiany zawartości pliku dla opiekunów zasobów lub innych osób do tego upoważnionych. System rezerwacji zasobów oparty na systemie plików ma charakter rozproszony, ponieważ harmonogramy wykorzystania zasobów znajdują się w różnych folderach systemu plików należących do poszczególnych wydziałów i oddziałów.

Poziom II - powtarzalny, lecz intuicyjny. Rozproszony charakter systemu rezerwacji zasobów utrudnia uzyskanie informacji o dostępności lub niedostępności zasobu, nawet jeśli jest się do tego uprawnionym, gdyż nie zawsze wiadomo, w którym pliku znajduje się dany zasób. Trudno jest również uzgodnić najbardziej odpowiedni czas na zorganizowanie spotkania zespołu pracowników, gdyż harmonogramy poszczególnych pracowników przechowywane są w odrębnych plikach.

Przedstawione problemy rozwiązują systemy harmonogramowania i rezerwacji zasobów, gdyż elementami, które łączą poszczególne obiekty, są kalendarze. Funkcje systemów harmonogramowania pozwalają również na przełączanie się między wieloma widokami kalendarzy, takimi jak: dzień, tydzień, miesiąc, rok lub listą zadań do wykonania. W systemach tych można również często wykorzystywać mechanizmy „kliknij, przeciągnij i upuść”, co znacząco ułatwiała zarówno samo definiowanie rezerwacji, jak i jej zmianę. Do funkcjonalności systemów harmonogramowania i rezerwacji zasobów w szczególności można zaliczyć:

- przeglądanie kalendarza innych użytkowników lub zasobów,

- implementacja różnych poziomów uprawnień do kalendarza (odczyt lub odczyt oraz zapis/zmiana/kasowanie) dla różnych użytkowników, 
- dodawanie/redagowanie/kasowanie użytkowników, wydarzeń i zasobów,

- zarządzanie wydarzeniami o charakterze rekurencyjnym,

- konfigurowanie dodatkowych atrybutów wydarzeń i zasobów,

- sprawdzanie konfliktów oraz dopasowanie czasu pomiędzy kalendarzami, co pozwala na implementację mechanizmu organizacji spotkań,

- automatyczne powiadamianie o nadchodzących wydarzeniach,

- eksportowanie i importowanie kalendarzy do formatów zewnętrznych (np. iCalendar, vCalendar), co pozwala na synchronizację kalendarzy np. z urządzeniami mobilnymi,

- implementacja mechanizmów autoryzacji w procesie rezerwacji,

- tworzenie raportów dotyczących wykorzystania czasu i zasobu za dany okres.

Istnieją cztery systemy harmonogramowania i rezerwacji zasobów, które można implementować następująco:

1) systemy dostarczone przez dostawcę zewnętrznego - najczęściej w postaci oprogramowania serwerowego dostępnego przy użyciu przeglądarki internetowej lub aplikacji mobilnej. Ich zaletą jest brak konieczności ponoszenia wydatków inwestycyjnych przez użytkownika, gdyż całe rozwiązanie jest zapewniane przez dostawcę. Dużą popularność tego typu systemów zawdzięcza się powszechnie stosowanemu darmowemu rozwiązaniu o nazwie Google Calendar (https://www. google.com/calendar/). Rozwiązanie to nie jest jednak możliwe do zastosowania w sądach, ponieważ dane o użytkownikach, zasobach i kalendarzach przechowywane są poza sądem (i najprawdopodobniej poza obszarem Europejskiego Obszaru Gospodarczego). Na takie rozwiązanie nie zezwalają liczne przepisy prawa, takie jak np. ustawa o danych osobowych, RODO czy polityka bezpieczeństwa sądu;

2) system zintegrowany $z$ pocztą elektroniczną $i$ (lub) systemem wspomagania pracy zespołowej - przykładami są pakiety Zimbra i Microsoft Exchange zapewniające rozbudowane możliwości tworzenia systemów harmonogramowania i rezerwacji zasobów. Zarówno Zimbra, jak i MS Exchange zostały wdrożone w niektórych sądach biorących udział w projekcie pilotażowym. Dlatego tam, gdzie systemy te działają, rekomendowane jest włączenie funkcjonalności kalendarzy oraz zbudowanie systemu harmonogramowania i rezerwacji zasobów na podstawie istniejących mechanizmów. Również w przypadku decyzji wdrożenia dobrej praktyki „Informatyczne narzędzia komunikacji wewnętrznej na podstawie pakietu Zimbra" rekomendowane jest wdrożenie omawianego rozwiązania;

3) rozwiązanie będące częścią systemu zarządzania treścią - przykładem jest moduł JEvents będący częśsią składową systemu zarządzania treścią Joomla! Rozwiązanie to nie posiada aż tak rozbudowanych możliwości, jak systemy zintegrowane z pocztą elektroniczną i (lub) systemem wspomagania pracy zespołowej, jest jednak rozwiązaniem prostym do zaimplementowania, gdy sąd posiada swój portal intranetowy zbudowany na podstawie systemu zarządzania treścią. Rozwią- 
zanie takie jest rekomendowane w przypadku, gdy wdrożenie niniejszej praktyki ograniczy się do harmonogramowania niewielkiej liczby zasobów;

4) rozwiązanie stanowiące system niezależny - są to kompleksowe rozwiązania dla zastosowań związanych z harmonogramowaniem i rezerwacją zasobów. Najczęściej zbudowane są na podstawie serwera WWW (Apache), bazy danych (mySQL) oraz języka skryptowego (PHP) i relacyjnej bazy danych. Systemy te cechuje rozbudowana funkcjonalność oraz możliwość stosowania na dowolnych platformach systemowych, chociaż najczęściej na platformie Linux. Przykładami ww. systemów są phpSheduleIt oraz WebCalendar.

Poziom III - zdefiniowany. Koordynowanie pracy osób na kierowniczych stanowiskach jest ważnym działaniem, poprawiającym skuteczność i efektywność pracy organizacji. Zadanie to można uzyskać dzięki stworzeniu kalendarzy dla pracowników oraz udostępnianiu odpowiednim osobom informacji o ich zawartości. Zestawienie kalendarzy prezesa i wiceprezesów sądu, przewodniczących wydziałów i oddziałów może pozwolić np. na lepsze zaplanowanie wspólnych zebrań czy podział obowiązków w czasie sezonu urlopowego lub absencji chorobowej.

Poziom IV - kontrolowany i mierzalny. Proces rezerwacji zasobów może przebiegać w sposób mniej lub bardziej sformalizowany. Sformalizowana metoda rezerwacji zasobów pozwala na osiągnięcie wyższego stopnia kontroli nad całym procesem. Metoda ta jest specyficzna dla określonych grup zasobów, dlatego trudno jest podać jej ogólny schemat. Przy jej projektowaniu należy uwzględnić m.in. następujące czynniki:

- konieczność posiadania uprawnień określonych pracowników do rezerwacji zasobów,

- istnienie minimalnego okresu wyprzedzającego potrzebnego do rezerwacji zasobu,

- wymóg autoryzacji w procesie rezerwacji zasobu, a w przypadku zasobów krytycznych, autoryzacji wielokrotnej,

- forma realizacji procedury (np. formularz elektroniczny lub e-mail).

System rezerwacji zasobów dzięki wykorzystaniu raportowania pozwala na generowanie zestawień dotyczących stopnia ich wykorzystania. Dzięki tej funkcjonalności możliwe jest dokonanie zmian w strukturze posiadanych zasobów poprzez ewentualne ich przesunięcia pomiędzy jednostkami organizacyjnymi.

Poziom $V$ - zoptymalizowany. Mierniki wskazujące stopień wykorzystania zasobów są pierwszym elementem pozwalającym na optymalizację struktury posiadanych zasobów. Można jednak stosować bardziej zaawansowane metody analizy istniejącej bazy zasobów, np. analizę trendów związanych z obciążeniem zasobów wynikającą z cykliczności ich wykorzystania, analizę potrzeb użytkowników w zakresie rezerwacji zasobów czy ewentualną modyfikację modelu rezerwacji zasobów. 


\subsection{Uwagi końcowe}

Przedstawioną koncepcję modeli dojrzałości należy traktować jako punkt odniesienia. Rozwiązania proponowane na jej poszczególnych poziomach mogą być dowolnie dopasowywane do potrzeb organizacji. W praktyce może to w szczególności oznaczać, że niektóre rozwiązania poziomów wyższych mogą być stosowane pomimo niezaimplementowania pewnych rozwiązań poziomów niższych. Niektóre sądy mogą być np. zainteresowane wdrożeniem jedynie kalendarza prezesa lub innych osób zajmujących kierownicze stanowiska bez implementacji kalendarzy dla innych zasobów. W każdym przypadku o ostatecznym kształcie zakresu zmiany powinny decydować rzeczywiste potrzeby organizacji. Zaleca się, aby każde z działań podjętych podczas implementacji praktyki było formalnie dokumentowane, co pozwala na uchronienie wypracowanych metod i narzędzi przed ich utratą w przypadku zmiany personelu.

Praktyka jest ściśle powiązana z inną praktyką - informatycznymi narzędziami komunikacji wewnętrznej. Zaleca się skoordynowanie działań w przypadku decyzji o jednoczesnym wdrażaniu ww. praktyki z praktyką opisaną w niniejszym dokumencie.

W przypadku korzystania z informatycznego systemu rezerwacji zasobów w sposób zdalny, tzn. poza budynkiem sądu, zaleca się zachowanie szczególnej staranności w definiowaniu uprawnień dla użytkowników i zasobów, mając na uwadze wymagania polityki bezpieczeństwa.

\section{Wnioski z wdrożenia dobrej praktyki informatycznego systemu rezerwacji zasobów}

Dobra praktyka „Informatyczny system rezerwacji zasobów” została wdrożona w 19 sądach: w 14 w ramach pilotażu podstawowego i w 5 sądach w ramach pilotażu uzupełniającego (Badanie ewaluacyjne... 2015). Wśród sądów, które wybrały dobrą praktykę, był m.in. Sąd Apelacyjny w Białymstoku, Sąd Okręgowy w Warszawie, Sąd Rejonowy w Pruszkowie oraz Sąd Rejonowy w Stalowej Woli. Harmonogram wdrażania oraz omówienie poziomu zaawansowania prac w poszczególnych sądach pilotażowych zamieszczono w opracowaniu (Raport całościowy... 2014).

Z opublikowanych raportów i informacji uzyskanych podczas współpracy autora z firmą wdrażającą wyciągnięto kilka wniosków. Wdrożenie dobrej praktyki miało pozytywny wpływ na proces zarządzania zasobami rzeczowymi w sądach, które ją wybrały. W szczególności dokonano rozszerzenia puli zasobów podlegających rezerwacji. W większości przypadków w sytuacji przedwdrożeniowej jedynym zasobem, który podlegał elektronicznej rezerwacji, były sale 
rozpraw. Pozostałe zasoby były rezerwowane ręcznie, często w sposób nieformalny, a metody miały charakter rozproszony. Po wdrożeniu systemu zasoby podlegające elektronicznej rezerwacji zostały rozszerzone o samochody, sale konferencyjne, systemy multimedialne, „błękitny pokój” itp.

Po zakończonym wdrożeniu, na podstawie przeprowadzonych ankiet i wywiadów z pracownikami sądów, wskazano najważniejsze zalety i ograniczenia dobrej praktyki oraz oceniono jej efekty. Do głównych zalet opisywanej dobrej praktyki należą:

- stworzenie nowego, przejrzystego intranetu,

- usprawnienie i uproszczenie procesu rezerwacji sprzętu komputerowego, pokoju konferencyjnego, „błękitnego pokoju”,

- skrócenie czasu procesu rezerwacji zasobów,

- możliwość wcześniejszego zgłaszania zapotrzebowania na zasoby,

- zwiększenie kontroli nad obsługiwanymi zasobami.

Do głównych ograniczeń opisywanej dobrej praktyki zaliczono:

- niewystarczające dopasowanie do specyfiki określonego sądu,

- ustalenie uprawnień użytkowników systemu.

Za najważniejsze efekty związane $\mathrm{z}$ wdrożeniem dobrej praktyki uznano:

- odciążenie pracowników w wydziałach od rozmów telefonicznych z interesariuszami,

- lepsze zarządzanie ograniczonymi zasobami, a w rezultacie lepsze wykorzystanie zasobów,

- poprawę funkcjonowania organizacji przejawiającą się uporządkowaniem procesów w firmie oraz $\mathrm{w}$ wielu przypadkach także zwiększeniem efektywności pracy w organizacji.

Autor wyraża przekonanie, że zaprezentowane podejście badawcze pozwoliło na wybór tych rozwiązań, które są nie tylko odpowiednie dla środowiska sądowniczego w sensie formalnych wymogów, ale także akceptowalne w sensie społecznym. Na kolejnym etapie badań zespół ekspertów przygotuje plan działań w celu oceny efektów wdrożenia dobrych praktyk informatycznych.

\section{Literatura}

Badanie ewaluacyjne pilotażu wdrażania dobrego zarzqdzania jednostkami wymiaru sprawiedliwości w ramach projektu „PWP Edukacja w dziedzinie zarzqdzania czasem i kosztami postępowań sqdowych - case management". Raport końcowy (2015), ASM - Centrum Badań i Analiz Rynku, Kutno.

Baskerville R.L. (1999), Investigating Information Systems with Action Research, Communications of the Association for Information Systems, vol. 2, Article 19, http://aisel. aisnet.org/cais/vol2/iss1/19 (data dostępu: 15.09.2014). 
Baskerville R.L., Wood-Harper A.T. (1996), A Critical Perspective on Action Research as a Method for Information Systems Research, ,Journal of Information Technology”, vol. 11, nr 3, https://doi.org/10.1080/026839696345289.

Bueno T.C.D., Bortolon A., Hoeschl H.C., Mattos E.S., Santos C.S., Theiss I. (2003), Using $R B C$ to Classify Judicial Petitions on e-Court, Proceedings of the 9th international conference on Artificial intelligence and law, ICAIL '03, June 24-28, Edinburgh, Scotland, UK.

Chircu A.M., Kauffman R.J., Keskey D. (2001), Maximizing the Value of Internet-based Corporate Travel Reservation Systems, Communications of The ACM, vol. 44, nr 11.

COBIT 4.1. Metodyka. Cele kontrolne. Wytyczne zarzq̨dzenia. Modele dojrzałości (2010), IT Governance Institute, Stowarzyszenie Audytu, Bezpieczeństwa i Kontroli Systemów Informacyjnych ISACA, Warszawa.

Cole M., Avison D. (2007), The Potential of Hermeneutics in Information Systems Rese$\operatorname{arch,~,European~Journal~of~Information~Systems”,~vol.~16,~nr~6,~https://doi.org/10.1057/~}$ palgrave.ejis.3000725.

Copeland D.G., McKenney J.L. (1988), Airline Reservation Systems: Lessons from History, „MIS Quarterly”, vol. 12, nr 3.

Davison R.M., Martinsons M.G., Kock N. (2004), Principles of Canonical Action Research, ,Information Systems Journal”, vol. 14, nr 1, https://doi.org/10.1111/j.1365 -2575.2004.00162.x.

Duliba K.A., Kauffman R.J., Lucas H.C. Jr (2001), Appropriating Value from Computerized Reservation System Ownership in the Airline Industry, „Organization Science”, vol. 12 , nr 6.

Gorham U. (2012), State Courts, e-filing, and Diffusion of Innovation: A Proposed Framework of Analysis, dg.o '12, Proceedings of the 13th Annual International Conference on Digital Government Research, June 04-07, College Park, Meryland, USA.

Grabowski M. (2018), Koncepcja zarzqdzania zasobami i usługami informatycznymi w sqdach powszechnych, ,Zeszyty Naukowe Uniwersytetu Ekonomicznego w Krakowie", nr 6(978), https://doi.org/10.15678/ZNUEK.2018.0978.0611.

Grabowski M., Madej J., Trąbka J. (2018), Koncepcja metodyki projektowania i wdrażania dobrych praktyk informatycznych dla sqdów powszechnych, ,Zeszyty Naukowe Uniwersytetu Ekonomicznego w Krakowie”, nr 4(976), https://doi.org/10.15678/ ZNUEK.2018.0976.0413.

ITGI (2007), Control Objectives for Information and Related Technology (COBIT) 4.1, IT Governance Institute, Rolling Meadows, IL.

Lin Y.L., Lee T.J. (2010), The Impacts of the Online Reservation Systems in London City Hotels, ,Journal of Hospitability Marketing \& Management”, vol. 19.

Luzuriaga, J.M., Cechich A. (2011), Electronic Notification of Court Documents: A Case Study, Proceedings of the 5th International Conference on Theory and Practice of Electronic Governance, ICEGOV ‘11, September 26-28, Tallinn, Estonia.

Paulk M.C., Weber C.V., Curtis B., Chrissis M.B. (1993), Capability Maturity Model for Software (Version 1.1), Technical Report CMU/SEI-93-TR-024 ESC-TR-93-177, February, Software Engineering Institute, Carnegie Mellon University, Pittsburgh, PA, https://resources.sei.cmu.edu/asset_files/TechnicalReport/1993_005_001_16211.pdf (data dostępu: 13.04. 2018).

Raport całościowy z wdrożenia za okres od 1 grudnia 2013 r. do 24 października 2014 r. (2014), oprac. WYG International, WYG Consulting, WYG PSDB, Uniwersytet Eko- 
nomiczny w Krakowie, Instytut Allerhanda na zlecenie Krajowej Szkoły Sądownictwa i Prokuratury, http://www.efs2007-2013.gov.pl/Dokumenty (data dostępu: grudzień 2016).

Vries E. (2007), Rigorously Relevant Action Research in Information Systems, University of Amsterdam, The Netherlands, Sprouts: Working Papers on Information Systems, 7(4), http://sprouts.aisnet.org/7-4 (data dostępu: 19.04. 2014).

Wade M., Hulland J. (2004), Review: The Resource-Based View and Information Systems Research: Review, Extension, and Suggestions for Future Research Quick View, „MIS Quarterly”, vol. 28, nr 1.

\section{Computerised Resource Management System in Common Courts}

(Abstract)

The paper describes good practice as it applies to a computerised resource management system. The concept of the good practice was developed during the implementation of a pilot study of good governance of judiciary units as a part of the project "PWP Education in time and cost management of judicial proceedings - case management" of the Human Capital Programme. The paper presents a detailed description of good practice objectives and the effects of their implementation.

Keywords: organisational resources, good practice, judiciary, information technology. 